\title{
DETERMINATION OF THE OPTIMUM CONDITIONS FOR BIOSURFACTANT PRODUCTION BY LOCAL ISOLATE OF LACTOBACILLUS PLANTARUM AND EVALUATE ITS ANTIMICROBIAL ACTIVITY
}

\author{
A .A. Jameel \\ Researcher \\ N. H. Haider \\ Prof.
}

Depart. of Biotech, Coll. Sci, University of Baghdad - Iraq

Email: Hamzazen10@yahoo.com

\section{ABSTRACT}

Eighty five local isolates of Lactobacillus sp. which were isolated from different sources and identified by biochemical test then subjected to the primary and secondary screening processes to select the active Lactobacillus sp. isolate for biosurfactant production. Among the isolates screened, twenty six isolates with maximum for tests in primary screening were selected for secondary screening. It has been found that Lactobacillus sp. ADK2 had the highest productivity of the biosurfactant. The selected isolate with highest level of biosurfactant activity was identified as Lactobacillus plantarum ADK2 according to PCR technique. The optimum conditions of biosurfactant production by isolate Lactobacillus plantarum ADK2 using submerged fermentation were obtained in the synthetic mineral salt medium (MSM) and natural BCDFTM medium the best production medium separately, $1.5 \%$ (lactose and egg) as the best carbon source, 2\% meat extract and 3.5\% Pease as nitrogen source, temperature $30{ }^{\circ} \mathrm{C}$ for two media and $\mathrm{pH} 5$ with $\mathrm{pH} 3$ in MSM and BCDFTM respectively, after $96 \mathrm{hr}$ and $72 \mathrm{hr}$ in MSM and BCDFTM respectively of incubation period.

KEYWORDS: Emulsification, lipopeptide, BCDFTM medium.

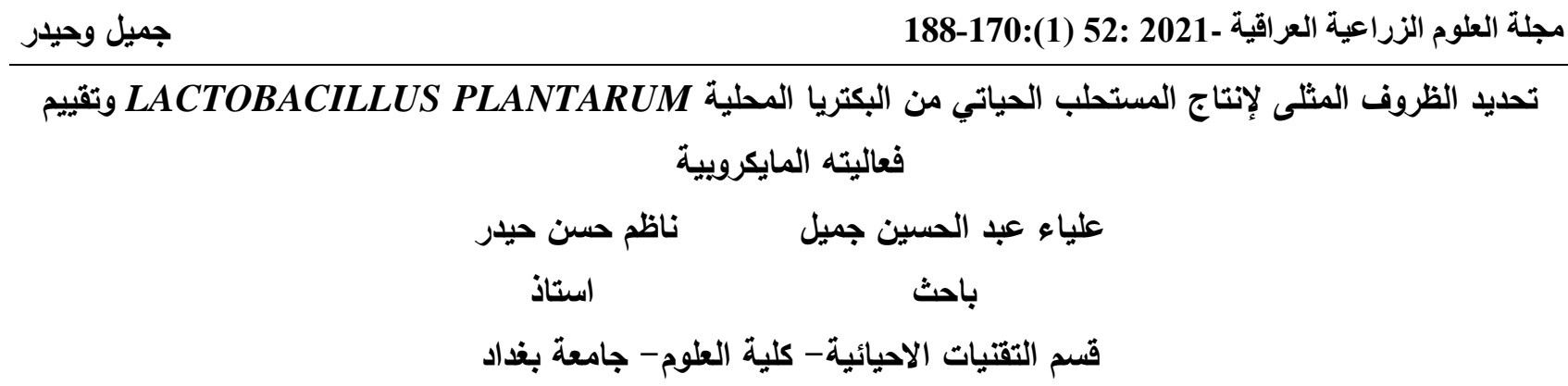

المستخلص

تم عزل خمسة وثمانون عزلة من بكتريا ـ Lactobacillus sp من مصادر مختلفة وشخصت باختبارات كيموحيوية ثم

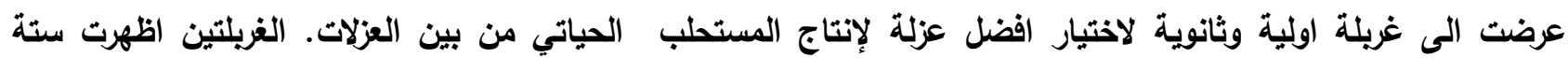
وعشرون عزلة افضل انتاج للمستحلب الحياتي من الغريلة الاولية واختيرت للغزبلة الثانية وجلت من خلال النتائج بان العزلية

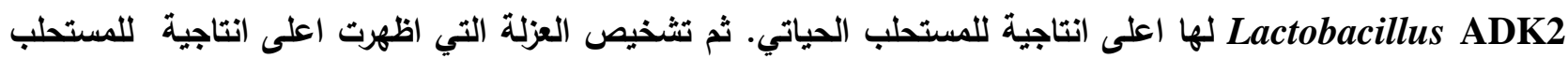
الحياتي يانها L.plantarum ADK2 بالاعتماد على تقتيات تفاعل البلمرة PCR ـ ثم تحديد الظروف المثلى لإنتاج المستحلب العياتي من قبل العزلة L.plantarum ADK2 باستخدام عمليات تخمير المفمور في وسط الاملاح المعدنية المصنع وفي الوسط الطبيعي (BCDTTM) بشكل منفصل . افضل وسط كاريوني كان باستخدام 1.5\% من النلاكتوز والبيض, 2 2 مستخلص اللحم و 3.5 من البزاليا كمصدر نتروجيني , افضل حرارة كان 30\% للوسطين اعلاه, افضل رقم هيدرجيني 5 لوسط الاملاح المعدنية و 3 في الوسط الطبيعي بعد 96 ساعة من التخمير في وسط الاملاح المعدنية المصنع و 72 ساعة في الوسط الطبيعي. دئي

الكلمات المفتاحية: استحلاب، البيتيد الدهني، وسط انتاج BCDFTM

Received:16/2/2020, Accepted:17/5/2020 


\section{INTRODUCTION}

Biosurfactants are surface active agents with wide range of properties including reduction of surface and interfacial tensions of liquids, Surface active compounds produced by microorganisms are of two main types; first, that reduce surface tension at the air water interface (biosurfactants) and second, that reduce interfacial tension between immiscible liquids, or at the solid-liquid interface bioemulsifier (45). Surfactants are extensively used for industrial, agricultural, food, cosmetic and pharmaceutical applications. Most of these surfactants are chemically synthesized and are potentially toxic to the environment. (44) Biosurfactants usually display emulsifying capacity but bioemulsifier do not necessarily reduce surface tension .Biosurfactants have important advantages relative to chemically synthesized surfactants, such as higher biodegradability, low toxicity, greater environmental compatibility, better foaming properties and stable at extreme $\mathrm{pH}$, salinity and temperature.(32) Microbial surfactants are considered to be secondary metabolites, play important role for the survival of biosurfactant producing microorganisms by facilitating nutrient transport or microbe-host interactions or by acting as biocide agents $(26,29)$, bacterial pathogenesis and biofilm formation. $(8,9)$ Bacteria are the main group of biosurfactantproducing microorganisms, although they are also produced by some yeasts and filamentous fungi, These compounds can be synthesized by microorganisms growing on water-immiscible hydrocarbons, as well as on water-soluble compounds such as glucose, sucrose, glycerol, or ethanol, and can be excreted or remain attached to the cell wall (33). Diversity existing among the biosurfactant-producing microorganisms suggests that their production represents an important survival strategy and appears to have evolved in an independent, yet parallel fashion (30). A number of studies have reported the potential of lactobacilli as biosurfactant producers (43). Biosurfactants isolated from several lactobacilli have been characterized as multicomponent mixtures, consisting of protein and polysaccharides, in other cases, the surface active compounds were identified as glycolipids (53). The chemical structure of the biosurfactants produced by lactobacilli was examined from different bacterial species: the L.helveticus derived biosurfactant is mainly constituted by lipid and sugar fractions; the L.pentosus, L.lactis and L.paracasei biosurfactants are glycoproteins or glycolipopeptides, while the L.plantarum biosurfactants are of glycolipidic or glycoproteic nature (14). Currently, the main factor that prevents the widespread use of biosurfactants is the process economics, and many strategies have been developed to reduce its production costs and make fermentation competitive with chemical synthesis (39). The use of inexpensive substrates like agroindustrial wastes, medium and culture conditions optimization, development of efficient recovery process, and the engineering of the producer microorganisms can contribute to make their production more economically attractive through the development of cheaper and efficient processes (41,48). Future biosurfactant research should, therefore, be more focused on the economics of the production processes, particularly through the use of alternative low-cost fermentative media (22). The antimicrobial activity of two biosurfactants obtained from probiotic bacteria, Lactococcus lactis 53 and Streptococcus thermophilus A, have been investigated against a variety of bacterial and yeast strains isolated from explanted voice prostheses and it was found that both the biosurfactants have a high antimicrobial activity even at low concentration (39). Probiotics have long been known for their antimicrobial activity and for the capacity to interfere with the adhesion and formation of biofilms of pathogens to epithelial cells of urogenital and intestinal tracts, catheter materials and voice prostheses and the mechanisms of this interference have been demonstrated to include, among others, the release of biosurfactants (40). The Current study was aimed to collect and identify of local isolates of Lactobacillus sp., as well as screening and evaluation the ability of local isolates for production of biosurfactant, determination the optimum conditions for biosurfactant production from selected isolate by using synthetic and neutral medium. 


\section{MATERIALS AND METHODS}

Chemicals and new natural medium

MRS agar, and all other reagent grand chemicals were purchased from Oxoid, HiMedia and Sigma - Aldrich, India, and natural products, fruits and vegetable were obtained from local market.

\section{Samples collection and bacterial isolation}

One hundred fifteen samples were collected from different sources as follow: (humans, dairy products, fermented fruits, vegetables, salted shrimp, pickles and al-sadder honey) (Table 1). One gm. of (fermented fruits, vegetables and salted shrimp) and one $\mathrm{ml}$ of (dairy products, pickles and al-sadder honey) were added to $9 \mathrm{ml}$ of MRS broth and incubated at $37^{\circ} \mathrm{C}$ for $48 \mathrm{hr}$. in the presence of $3-5 \% \mathrm{CO}_{2}$ by using Candle Jar, then one $\mathrm{ml}$ of sample was added to $9 \mathrm{ml}$ of $0.1 \%$ peptone water in test tubes and dilution steps when carried out until $10^{-6}$ were done. Then samples were cultured on MRS agar medium and incubated at $37^{\circ} \mathrm{C}$ for $48 \mathrm{hr}$. in the presence of $3-5 \% \mathrm{CO}_{2}$ by using Candle Jar (13). To prevent the growth of fungal in cultures, $0.1 \%$ antifungal (Nystatin) was added to cultures. The isolates were purified by sub culturing on MRS- agar as a selective media (12), then the purified colonies were maintains on the same media, thereafter gram staining, biochemical tests, grown on blood, chocolate agar. The highest production isolates were identified by PCR, these isolates were prepared for screening experiments for biosurfactant production according to method described by Anandaraj and Thivakaran (4).

Screening the Lactobacillus sp. isolates for biosurfactant production

Primary screening (semi-quantitative screening)

Screening of isolates in blood agar plate medium (Hemolysis test): Eighty five isolates of Lactobacillus sp. were screened to select higher producing isolates for biosurfactant production by plate assay using blood agar medium. One hundred microliter of bacterial culture previously activated in MRS broth was filled into the each well made in blood agar medium using cork borer, and then incubated at $37^{\circ} \mathrm{C}$ for $24 \mathrm{hr}$. in different aeration conditions (aerobic and anaerobic using anaerobic Jar). growth zone around the wells was indication of biosurfactant secretion. The radius of a zone was measured using electronic ruler in $\mathrm{mm}(4)$.

Table 1. Different sources were collected for Lactobacillus isolation

\begin{tabular}{|c|c|c|}
\hline Samples & No. of samples & Source \\
\hline \multicolumn{3}{|c|}{ Humans } \\
\hline Vaginal swabs & 40 & $\begin{array}{l}\text { Were obtained from } \\
\text { healthy premenopausal } \\
\text { women in Medical City } \\
\text { Hospital, Baghdad }\end{array}$ \\
\hline Mouth cavity & 10 & healthy people from \\
\hline Salvia & 10 & $\begin{array}{c}\text { male and female with } \\
\text { ages between (20-30) } \\
\text { years }\end{array}$ \\
\hline Colostrum & 10 & During breastfeeding \\
\hline Feces new born & 13 & 10-40 days \\
\hline \multicolumn{3}{|c|}{ Dairy products } \\
\hline Goat milk & 4 & Locally \\
\hline Goat cheese & 4 & Turkey \\
\hline Canoon & 4 & Iraq \\
\hline Activia & 4 & Iraq-Irbil \\
\hline \multicolumn{3}{|c|}{ Fermented Fruits and vegetables } \\
\hline Lemon & 2 & Locally \\
\hline Orange & 2 & Locally \\
\hline Orange mandarin & 2 & Locally \\
\hline Banana & 2 & Locally \\
\hline Tomato & 2 & Locally \\
\hline \multicolumn{3}{|c|}{ Other sources } \\
\hline Salted shrimp & 2 & Turkey \\
\hline Pickles & 2 & Locally \\
\hline Al-Sadder honey & 2 & Locally \\
\hline
\end{tabular}


Screening of isolates in phenol red plate medium: All 64 isolates were grown on phenol red agar medium containing $(\mathrm{g} / \mathrm{l})$ (Agar-Agar 15 gm, $\mathrm{FeSO}_{4} .7 \mathrm{H}_{2} \mathrm{O} 0.00028 \mathrm{gm}$, $\mathrm{K}_{2} \mathrm{HPO}_{4} 4.4 \mathrm{gm}, \mathrm{KCl} 1.1 \mathrm{gm}, \mathrm{KH}_{2} \mathrm{PO}_{4} 3.4 \mathrm{gm}$, $\mathrm{MgSO}_{4} \cdot 7 \mathrm{H}_{2} \mathrm{O} 0.5, \mathrm{NaCl} 1.1 \mathrm{gm}, \mathrm{NaNO}_{3} 15 \mathrm{gm}$, Peanut oil1.0 \% (w/v), Yeast extract $0.5 \mathrm{gm}$, with adding 0.2 of Phenol red gave dark blue zone. Then the clear zone that ferreted were measured by electronic ruler.

Screening of isolates in blue agar plate medium: All 45 isolates that grown on previous media gave the clear zone were culture on $\mathrm{CTAB} /$ methylene blue agar medium containing (g/l) (Agar-Agar 15g, CTAB 0.2g, Glucose 5g, Methylene blue $0.005 \mathrm{~g}$, Peptone $10 \mathrm{~g}$, and Yeast extract $0.5 \mathrm{~g}, \mathrm{pH}$ was adjusted to 7.3). One hundred microliter of bacterial culture previously activated in MRS broth was loaded into the each well prepared in MSM with $\mathrm{CTAB} /$ methylene blue using cork borer, and then incubated at $37^{\circ} \mathrm{C}$ for $48 \mathrm{hr}$. in different aeration conditions (aerobic and anaerobic by using anaerobic Jar). A dark blue halo zone appearance around the culture was an indication of biosurfactant secretion. The radius of inhibition zone was measured using electronic ruler in $\mathrm{mm}$.

\section{Drop collapse assay}

In this method all 42 isolated tested, the interfacial tension between the drop containing the surfactant and the parafilm surface is reduced which results in the spread of the drop. Twenty five microliter of fresh bacterial culture which activated in MRS broth previously conditions, were pipetted as a droplet on the parafilm. Distilled water was used as negative control. The flattening of droplet and spreading of the droplet on the parafilm surface was observed. safranin was added for staining purpose (55).

\section{Penetration assay}

In this assay, the cavities of a 96 well microplate were filled with $150 \mu \mathrm{l}$ of a hydrophobic paste made up of oil and silica gel. The paste was covered with $20 \mu$ of oil. $10 \mu \mathrm{l}$ of a red staining solution (safranin) was added to $90 \mu \mathrm{l}$ of the bacterial culture for all 36 isolates. The coloured bacterial culture was then placed on the surface of the paste (31).
Oil spreading test: All 9 isolates tested, twenty $\mathrm{ml}$ of distilled water was added to a petri plate then $20 \mu \mathrm{l}$ of engine oil were add to the surface of water. Twenty microliter of bacterial culture, were placed onto the center of oil membrane. Diameter of clearly oil displaced circles was measured (33).

Screening of isolates in crystal violet plate medium: All 8 isolates that gave a positive results on the previous test were selected and cultured on crystal violet agar medium containing previous media (phenol red plate above) with addition $100 \mu \mathrm{l}$ of crystal violet replacement phenol red. The isolate were screened as in previous experiment above.

\section{Biuret test}

The Biuret test was used to detect the presence of lipopeptide biosurfactants for six isolates. Two $\mathrm{ml}$ of the bacterial culture which growing in different aeration conditions (aerobic and anaerobic in anaerobic Jar), were heated at 70 ${ }^{\circ} \mathrm{C}$ before mixing with $1 \mathrm{M} \mathrm{NaOH}$ solution. Then, drops of $1 \% \mathrm{CuSO} 4$ were slowly added to observe any color change violet or pink ring (15).

\section{Secondary screening (quantitative screening)}

Biosurfactant production in liguid media: Tow isolates with maximum productivity based from primary screening were selected and cultivated on MSM containing $(\mathrm{g} / \mathrm{l})\left(\mathrm{CaCl}_{2}\right.$ . $2 \mathrm{H} 2 \mathrm{O} 0.1 \mathrm{~g}, \mathrm{FeSO}_{4} .7 \mathrm{H}_{2} \mathrm{O} 0.05 \mathrm{~g}, \mathrm{~K}_{2} \mathrm{HPO}_{4}$

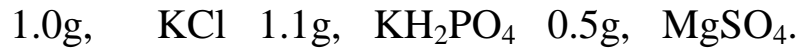
$7 \mathrm{H}_{2} \mathrm{O} 0.6 \mathrm{~g}, \mathrm{MnSO}_{4} .7 \mathrm{H} 2 \mathrm{O} 0.03 \mathrm{~g}, \mathrm{Na}_{2} \mathrm{MoO}_{4}$. $2 \mathrm{H} 2 \mathrm{O} \quad 0.001 \mathrm{~g}, \quad \mathrm{NaCl} 5.0 \mathrm{~g}, \mathrm{NH}_{4} \mathrm{NO}_{3} 1.0 \mathrm{~g}$, Peanut oil $2.0 \%(\mathrm{w} / \mathrm{v}), \mathrm{pH}$ was adjusted to 6.2 ). A $250 \mathrm{ml}$ flasks containing $50 \mathrm{ml}$ of mineral salt medium was inoculated with $1.0 \mathrm{ml}\left(1 \times 10^{8}\right.$ cell $/ \mathrm{ml}$ ) of $48 \mathrm{hr}$. cultures of isolates. The flasks were incubated under shaking $(150 \mathrm{rpm})$ at $37{ }^{\circ} \mathrm{C}$ for $72 \mathrm{hr}$. in different aeration conditions (aerobic and anaerobic by using $\mathrm{N}_{2}$ gas (flashing system). Then, the cultures were centrifuged at $4{ }^{\circ} \mathrm{C}, 8000 \mathrm{rpm}$, for $10 \mathrm{~min}$. The clear supernatant was considered as extracellular biosurfactant production, the cells were washed twice with distilled water and resuspended in $10 \mathrm{ml}$ of phosphate buffer saline. The cells were then incubated at room temperature for $4 \mathrm{hrs}$. with gentle stirring for biosurfactant production. Thereafter, the broth was centrifuged at $8000 \mathrm{~g}$ for $10 \mathrm{~min}$. The 
supernatant was considered as intracellular biosurfactant. The supernatant was then filtered through sterile $0.22 \mathrm{~mm}$ pore size filter (Millipore) (52).

\section{Measurement of surface tension}

The surface tension of an aqueous solution was measured by the Wilhelmy platinum plate with a QBZY-2 Tensiometer (China). Twenty $\mathrm{ml}$ of supernatant was poured into $50 \mathrm{ml}$ glass beaker and put onto the tensiometer platform. The measurement was carried out at $25 \pm 1{ }^{\circ} \mathrm{C}$ after dipping the plate in the solution until monitoring the value of supernatant surface tension following the procedure of measurement written in the manual of the instrument. Between each measurement, the Wilhelmy plate was rinsed with acetone and burned by alcohol burner. For more accurate value, the average of three records was used in the study (45).

Determination of emulsification activity ( $E$ 24\%):Two $\mathrm{ml}$ of cell free supernatant was added to $2 \mathrm{ml}$ of toluene (equal volumes v/v), mixed with vortex for $2 \mathrm{~min}$., and left for 24 hrs. at room temperature, the height of emulsifier layer was measured. The emulsification index was given as a percentage of the height of the emulsified layer $(\mathrm{mm})$ to the total height of the liquid column $(\mathrm{mm})$ multiplied by 100 (10).
Bacterial adhesion to hydrocarbons (BATH): The hydrophobicity of the cells can be measured by BATH assay. Absorbance of the suspension was measured at $600 \mathrm{~nm}\left(\mathrm{~A}_{0}\right)$, A one hundred $\mu \mathrm{l}$ of motor oil was mixing with $2 \mathrm{ml}$ of cell suspension and was vortex shaken for $3 \mathrm{~min}$ in test tubes. After mixing, crude oil and aqueous phase were allowed to separate for 1hour. The aqueous phase was carefully removed. OD of the aqueous phase was then measured at $600 \mathrm{~nm}$ (A1) in a spectrophotometer (28). Hydrophobicity is expressed as the percentage of cell adherence to crude oil and was calculated as follows:

$\mathrm{H} \%=\left(\mathbf{1}-\mathrm{A} / \mathbf{A}_{0}\right) * 100$

\section{Identification of Lactobacillus spp}

The higher production Lactobacillus isolate of biosurfactant was identified by using sequences of the $16 \mathrm{~S}$ ribosomal RNA, DNA extraction, polymerase chain reaction (PCR). The universal bacterial primer set was used to amplify $16 \mathrm{~S}$ rRNA from the genomic. The PCR-amplified 16S rRNA fragments were amplified using two universal primers, 27F: $5^{-}$ AGAGTTTGATCCTGGCTCAG $3^{-}$and 1492R:5 CGGTTACCTTGTTACGACTT3.Primers. Solutions which used is $\mathrm{X}$ TAE buffer, loading dye, DNA ladder marker, Ethidium bromide $(10 \mathrm{mg} / \mathrm{ml})$. The PCR reaction mixture was prepared as (Table 2).

Table 2. Master mix components of PCR

\begin{tabular}{|c|c|c|c|c|c|}
\hline Master mix Components & Stock & Unit & Final & Unit & Volume 1 Sample \\
\hline Master Mix & 2 & $\mathbf{X}$ & 1 & $\mathbf{X}$ & 12.5 \\
\hline Forward primer & 10 & $\mu \mathbf{M}$ & 1 & $\boldsymbol{\mu} \mathbf{M}$ & 1 \\
\hline Reverse primer & 10 & $\mu \mathrm{M}$ & 1 & $\mu \mathbf{M}$ & 1 \\
\hline Nuclease Free Water & & & & & 8.5 \\
\hline DNA & 10 & $\mathrm{ng} / \mu \mathrm{l}$ & 10 & $\mathrm{ng} / \mu \mathrm{l}$ & 2 \\
\hline Total volume & & & & & 25 \\
\hline Aliquot per single rxn & & & & & $2 \mu \mathrm{l}$ of Template \\
\hline
\end{tabular}

The PCR cycling conditions for the set were a touchdown approach of 30 cycles as follows: 1 cycle of genomic DNA was initial denatured at $95^{\circ} \mathrm{C}$ for $1 \mathrm{~min}$, followed by 30 cycles of $95^{\circ} \mathrm{C}$ for $30 \mathrm{sec}, 60^{\circ} \mathrm{C}$ for $1 \mathrm{~min}$, and $72^{\circ} \mathrm{C}$ for $1 \mathrm{~min}$ with a final extension step I cycle of $72^{\circ} \mathrm{C}$ for $7 \mathrm{~min}$. A $10 \mathrm{~min}$ incubation at $10^{\circ} \mathrm{C}$ was added to the end of PCR program. PCR product were send for Sanger sequencing using ABI3730XL, automated DNA sequencer, by Macrogen Corporation - Korea. The results were received by email then analyzed using genious software.

\section{Optimum conditions of biosurfactant production}

Effect of fermentation media: The influence of different fermentation media on the production of biosurfactant was examined by cultivation the selected isolate Lactobacillus $s p$. (ADK2) in different culture media include synthetic media (MSM and MRS medium) and new natural media (Whey medium and BCDFT medium containing (g/l) Banana $5 \mathrm{~g}$, Corn 7g, Date 3g, Fig 3g, Tomato 4g). Erlenmeyer flasks $250 \mathrm{ml}$ containing $50 \mathrm{ml}$ of each tested medium in duplicates were 
sterilized and inoculated with $1 \% \quad\left(1 \times 10^{8}\right.$ cell $/ \mathrm{ml}$ ) of overnight culture of the isolate. The flasks were incubated in a shaker incubator $(150 \mathrm{rpm})$ at $37{ }^{\circ} \mathrm{C}$ for $72 \mathrm{hr}$. in anaerobic conditions by using $\mathrm{N}_{2}$ gas (flashing system). After incubation, the cultures were centrifuge at $8000 \mathrm{rpm}$ for $10 \mathrm{~min}$. The cells from each flask were washed twice in distilled water and resuspended in $10 \mathrm{ml}$ of phosphate buffer saline. The cells were then incubated at room temperature for $4 \mathrm{hrs}$., with gentle stirring for biosurfactant production. After 4 hrs, the broth was centrifuged at $8000 \mathrm{~g}$ for 20 min.The supernatant was taken for determination the emulsification activity and surface tension in all the following experiments.

\section{Effect of $\mathbf{p H}$}

Erlenmeyer flasks $(250 \mathrm{ml})$ containing $50 \mathrm{ml}$ of the selected fermentation media (new natural media BCDFTM and synthetic media MSM) were adjusted using $0.1 \mathrm{~N} \mathrm{HCL}$ or $0.1 \mathrm{~N}$ $\mathrm{NaOH}$ to obtain different $\mathrm{pH}$ values $(3,4,5,6$, 7, 8 and 9) ,150 rpm at $37^{\circ} \mathrm{C}$ for $72 \mathrm{hr}$, then the culture medium was inoculated with $1 \%$ of overnight culture of the selected isolate $\left(1 \times 10^{8} \mathrm{cell} / \mathrm{ml}\right)$ as previous experiment above.

\section{Effect of temperature}

Biosurfactant production was achieved at different temperatures $(15,30,44,53$, and $60^{\circ} \mathrm{C}$ ) . Before sterilization the media, the $\mathrm{pH}$ was adjusted to (3.0 in natural media and 5.0 in synthetic media), then sterilized and inoculated with $1 \%$ of overnight culture $\left(1 \times 10^{8}\right.$ cell $/ \mathrm{ml}) 150 \mathrm{rpm}$ of the selected isolate (ADK2) as in previous experiment above.

\section{Effect of agitation speed}

Different rpm values (120, 140, 180, 200 and $220 \mathrm{rpm}$ ) were examined to determine the optimum shaking required to obtain the high biosurfactant activity. The synthetic with $\mathrm{pH}$ 5.0 and natural media with $\mathrm{pH} 3.0$ at $30^{\circ} \mathrm{C}$ were prepared and inoculated with of selected isolate then incubated at selected $\mathrm{rpm}$ as above.

\section{Effect of carbon sources}

Different carbon sources were used in MSM include (fructose, sucrose, glycerol, starch, and lactose), while boiled rice water, frying oil, beef, cheese, and egg (47) were added separately in new natural medium respectively to determine the optimum carbon source for biosurfactant production, each of these sources was added to the medium in $(1 \mathrm{~g} / 100 \mathrm{ml})$. Then, $\mathrm{pH}$ was adjusted to 5.0 in MSM and 3.0 in new natural medium at $30^{\circ} \mathrm{C} 120 \mathrm{rpm}$, and inoculated with $1 \%$ of overnight culture $\left(1 \times 10^{8}\right.$ cell $/ \mathrm{ml}$ ) of the selected isolate (ADK2) as previous experiment above.

\section{Effect of carbon source concentration}

Different concentrations (1.5, 2, 2.5, 3 and 3.5 $\%)$ of (egg and lactose) as a carbon sources were used in synthetic and neutral media respectively to grow the bacterium in order to determine the optimum concentration of selected carbon sources for biosurfactant production. $\mathrm{pH}$ was adjusted to 3.0 and 5.0 at $30^{\circ} \mathrm{C}$ in $120 \mathrm{rpm}$ respectively. The flasks were inoculated with $1 \%$ of overnight culture $\left(1 \times 10^{8}\right.$ cell $/ \mathrm{ml}$ ) of the selected isolate (ADK2) as previous experiment above.

\section{Effect of nitrogen sources}

To determine the effect of nitrogen source on biosurfactant production medium, synthetic fermentation media supplemented with $(1 \mathrm{~g} / 100 \mathrm{ml})$ of different nitrogen sources ( yeast extract, meat extract, urea, peptone, and $\mathrm{NaNO}_{3}$ ) in $\mathrm{MSM}$, at $\mathrm{pH} 5.0$, while in new natural medium using (peas, chickpeas, oat, potato, peach), pH 3.0 at $30^{\circ} \mathrm{C}$ in $120 \mathrm{rpm}$. After sterilization, the flasks were inoculated with $1 \%$ of overnight culture $\left(1 \times 10^{8}\right.$ cell $\left./ \mathrm{ml}\right)$ of the selected isolate (ADK2) as in previous experiment above.

\section{Effect of nitrogen source concentration}

The optimal nitrogen sources (peas and meat extract) were added in gradual concentration( $(1.5,2,2.5,3$ and $3.5 \%)$ to the new natural media and mineral salt medium respectively. $\mathrm{pH}$ was adjusted to 3.0 and 5.0 at $30^{\circ} \mathrm{C}$ in $120 \mathrm{rpm}$ respectively, then inoculated with $1 \%$ of overnight culture $\left(1 \times 10^{8}\right.$ cell $\left./ \mathrm{ml}\right)$ of the selected isolate (ADK2) as previous experiment above.

\section{Effect of incubation period}

In order to determine the optimum incubation time for biosurfactant production, the time course for biosurfactant production was followed $0,4,16,24,48,72,96,120$ and 144 $\mathrm{hr}, \mathrm{pH}$ was adjusted to 3.0 in natural media and 5.0 in MSM. The two media were prepared and inoculated with $1 \%$ of overnight culture $\left(1 \times 10^{8}\right.$ cell $\left./ \mathrm{ml}\right)$ of the selected isolate 
(ADK2) incubated in different time at $30^{\circ} \mathrm{C}$ in $120 \mathrm{rpm}$.

Antimicrobial activity of crude biosurfactant

A twenty $\mathrm{ml}$ Muller Hinton Agar was prepared for petriplates each. All the petriplates were swabbed with pathogenic isolates (Staphylococcus aureus and Pseudomoas aeruginosa). Fifty microliter of cell free supernatant was loaded into the each well prepared in MHA with using cork borer, and then incubated at $37^{\circ} \mathrm{C}$ for $48 \mathrm{hr}$. After incubation, the plates were checked for the appearance of zone of inhibition. The radius of inhibition zone was measured using electronic ruler in $\mathrm{mm}$ (59).

\section{RESULTS AND DISCUSSION}

Bacterial isolation and identification : One hundred fifteen samples were collected from different sources. The samples were primarily grown onto MRS agar plates as selective media for isolation and incubated at $37{ }^{\circ} \mathrm{C}$ for $48 \mathrm{hr}$. with the presence of (3-5\%) $\mathrm{CO}_{2}$ by using Candle Jar. The results were showed that only eighty five isolates were found belongs to genus Lactobacillus which subjected to morphological, microscopy, and biochemical tests in order to confirm their identification. The isolates were identified as related to the genus Lactobacillus by their small $(2-5 \mathrm{~mm})$, convex, smooth, glistening colonies, and opaque without pigment on MRS, no hemolysis on blood, chocolate agar as Figure 1-A, 1-B, and 1-C. Microscopically, the bacteria appeared under oil immersion lens $(100 x)$ as gram positive bacilli, arranged singly, pairs or short chains as shown in Figure 1-D . While the use biochemical test as compared with identification schematic diagram of Kotzamanidis et al, (28). Also the results were revealed that all isolates were negative for oxidase tests, catalase tests, and indole tests.

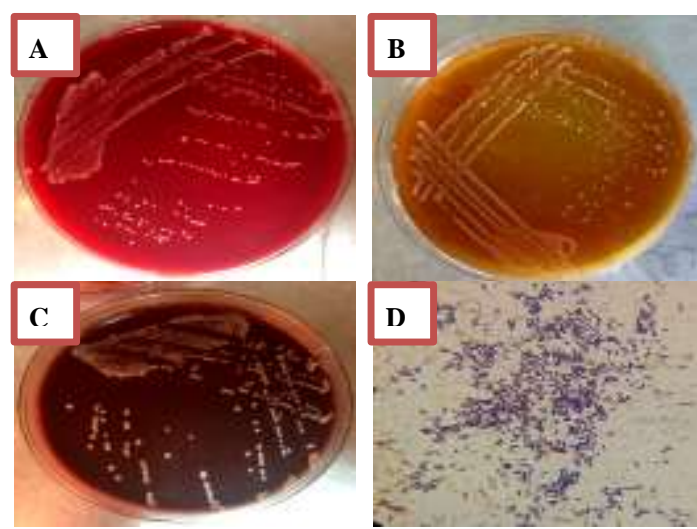

Figure 1. Microscopically and morphology examination of the Lactobacillus sp. bacterial isolates under large objective lens and different plates agar (A) grown on MRS agar (B) grown on blood agar (C) grown on chocolate agar and (D) visualized at $(100 x)$ under microscope.

Screening of Lactobacillus spp. isolates for biosurfactant production:

Primary screening (semi-quantitative screening)

Screening of isolates in blood agar plate medium (Hemolysis test : Hemolytic activity assay is a primary method for screening a biosurfactant producer. All eighty five isolates were screened on blood agar plates. Sixty four isolates showed positive results for haemolytic activity by formation of a clear zone around the colonies, with a diameter ranged from (9.18-26.14) $\mathrm{mm}$. The results also showed that the isolate (ADK2) revealed the highest clear zone $(26.14 \mathrm{~mm})$ under anaerobic condition (intracellular) Figure 2, this result indicated that the isolate Lactobacillus was able to produce biosurfactants. The blood agar method, is widely used to screen for biosurfactant production. Rodrigues and Teixeira (39) were showed that the culture of Lactobacillus species producing beta haemolysis was able to produce biosurfactants. Rodrigues et al, (40) showed that the size of the clear zone developed is in proportion to the amount of the produced biosurfactant. 


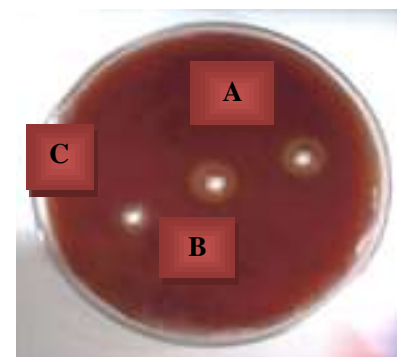

Figure 2. (A and B). Biosurfactant producing isolate ADK2 on blood agar medium (C): control using only distal water Screening of isolates in phenol red plate medium: Forty five isolates only were biosurfactant producer through the formation of clear inhibition zone of reduction around the phenol plate well Figure 3. These isolates gained different clearance zone ranged from (15.20-27.66) $\mathrm{mm}$. The isolate ADK2 showed the highest clear zone $(27.66 \mathrm{~mm})$ under anaerobic condition. phenol red or otherwise called Phenolsulfonphthalein is a $\mathrm{pH}$ indicator commonly used in cell biology laboratories. Is contain salt (sodium salt) this salt inhibits most bacteria dependent type of microorganisms, It is found in most culture media such as mannitol salt agar (MSA), modified oxford agar (MOX), XLT-4 Agar and HardyCHROM A agar (19).

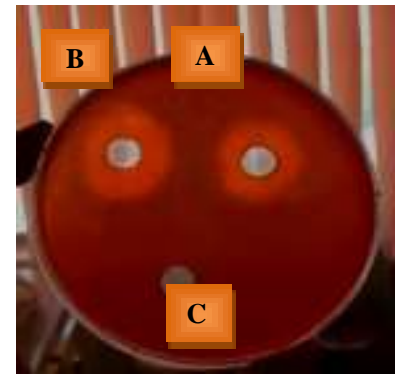

Figure 3. (A and B). Biosurfactant producing by $\mathrm{ADK} 2$ isolate on phenol red agar medium (C) control using only distal water

Screening of isolates in blue agar plate medium: Blue agar plate method is a semi quantitative agar plate method that is based on the formation of an insoluble ion pair of anionic surfactants with the cationic surfactant CTAB and the basic dye methylene blue. The results were revealed that the isolates had a positive activity on $\mathrm{CTAB}$ agar by formation dark blue halos in forty two isolates as in Figure 4, that indicating of biosurfactant production. The isolate ADK2 showed the highest clear zone $(29.21 \mathrm{~mm})$ under anaerobic condition. CTAB agar plate method is a semi quantitative assay for the detection of extracellular glycolipids or other anionic surfactants only (15). In the previous study revealed nearly $9.38 \%$ of isolates as positive for CTAB agar plate test, (36) recorded that $52.8 \%$ of isolates give positive results in CTAB.

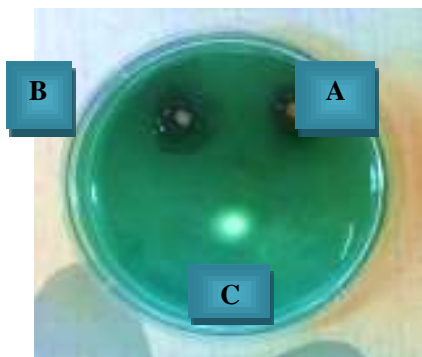

Figure 4. (A and B). Biosurfactant producing by ADK2 isolate on CTAB agar medium $(C)$ : control using only distal water

\section{Drop collapse assay}

This assay relies on the destabilization of liquid droplets by surfactants. Therefore, drops of a cell suspension or of culture supernatant were placed on an oil coated, solid surface. If the liquid does not contain surfactants, the polar water molecules were repelled from the hydrophobic surface and the drops remain stable. If the liquid contains surfactants, the drops spread or even collapse because the force or interfacial tension between the liquid drop and the hydrophobic surface was reduced. The stability of drops is dependent on surfactant concentration and correlates with surface and interfacial tension. Thirty six isolates gave positive results for drop collapse test Figure 5. Erum et al, (14) suggested that positive cultures for collapse of the oil drop resulted in better biosurfactant producer and certainly been involved in lowering the surface and interfacial tension between oil and water. The drop-collapse method is a sensitive and easy to perform method and has several advantages in requiring a small volume of samples, being rapid and easy to carry out, and not requiring specialized equipment (47).

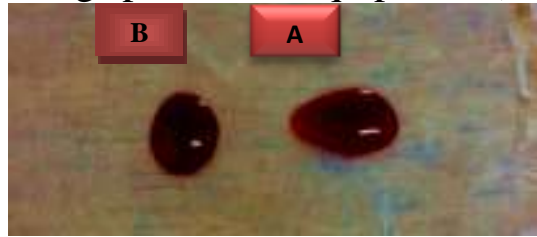

Figure 5. (A). Biosurfactant producing by

ADK2 isolate by drop collapse test $(B)$ control using only distal water 


\section{Penetration assay}

Out of the thirty six isolates selected for the screening studies, only nine bacterial isolates gave a positive result for penetration assay. The best result was obtained from isolate ADK2 Figure 6. Joshi et al, (26) were developed an assay suitable for high throughput screening for biosurfactant production called the penetration assay. This assay relies on the fact that if biosurfactant is present, the hydrophilic liquid will cross the oil layer and result in change in color from red to cloudy white. Pseudomonas aeruginosa was screened for biosurfactant production using penetration assay (35). Similar results were obtained by (39).
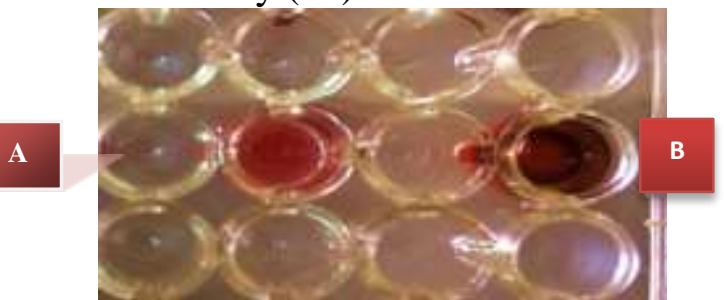

Figure 6. (A). Penetration assay for Lactobacillus(ADK2) producing

biosurfactant, (B) nagetive control using silica gel with oil

\section{Oil spreading test}

For oil spreading test, the bacterial culture was added in to engine oil containing plate. The biosurfactant producing organism would displace oil and form a clear zone in the center of the plate which indicates the ability of isolated organism to displace the oil. Only eight isolates showed the clear zone by being able to displace the oil around the colony indicating biosurfactant production were ranged from (8.94-47.87) $\mathrm{mm}$, the isolate ADK2 showed high surface activity by showing oil displacement in $47.87 \mathrm{~mm}$ diameter in anaerobic condition Figure 7. No clear zone was observed with control. Persson et al, (38) showed that the size of the clear zone developed is in proportion to the amount of the produced biosurfactant, the isolate L.rhamnosus showed the highest surface activity with oil displacement diameter (10 $\mathrm{mm})$ at $24 \mathrm{~h}$ of growth under anaerobic condition, $(8 \mathrm{~mm})$ both at $48 \mathrm{~h}$ of growth under aerobic and anaerobic condition, with the lower values at $72 \mathrm{~h}$.

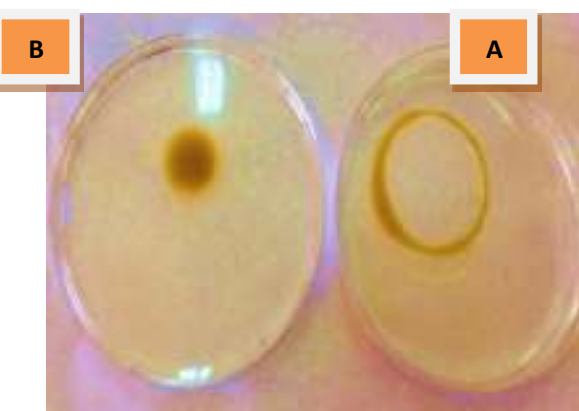

Figure 7. (A). Oil displacement assay for lactobacillus sp. ADK2 producing biosurfactant, (B) negative control using only oil

Screening of isolates in crystal violet plate medium: For more detection and selection of efficient bacterial isolates to biosurfactant production, the crystal violet solid medium were used by estimating the clear zone diameter around the plate wells as Figure 8. All 8 isolates were screened, the results were revealed that the six isolates were have a positive results for biosurfactant production. The clear zone of isolates were aranged from $(10.75-22.15) \mathrm{mm}$. The isolate ADK2 showed the highest clear zone $(22.15 \mathrm{~mm})$ under anaerobic condition. Crystal violet has an antibacterial action against microorganisms. The effect of the dye, measured as minimum inhibitory concentration or retardation of growth, increases as the $\mathrm{pH}$ rises from 6 to 8 . The mode of action put forward by (49) that the action of crystal violet is due to the formation of an unionized complex of bacteria with dye, is supported. (17) suggested that crystal violet might block important biological mechanisms, possibly connected with oxidation processes.

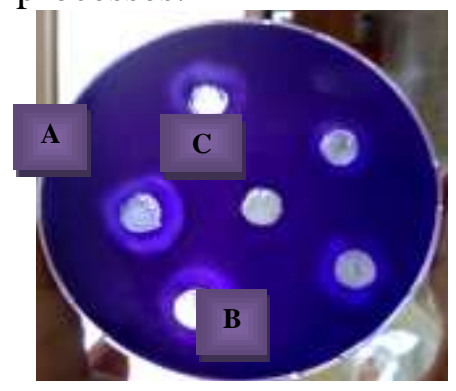

Figure 8. (A and B). Biosurfactant producing by ADK2 isolate on crystal violete agar medium $(C)$ control using only distal water

\section{Biuret test}

Biuret reagent was used to detect the presence of lipopeptide biosurfactants in the sample. A negative result was observed, no color change 
to violet, when crude biosurfactant extract was dissolved in Biuret reagent. All 6 isolates were screened for test, only two isolates have positive results (ADK2, ADK17) as Figure 9.

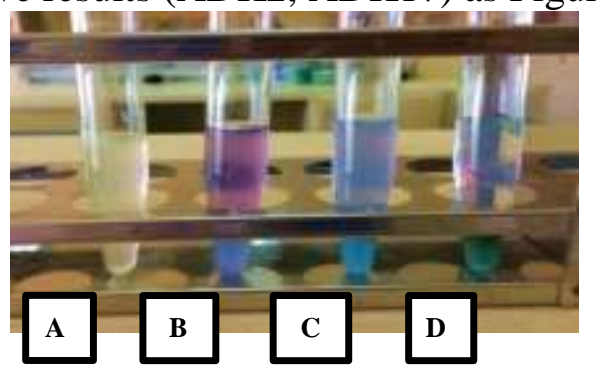

Figure 9. (A). nagetive control (B)

Lactobacillus sp. ADK2 producing

lipopeptide biosurfactant (C) non-

producing isolate (D) Lactobacillus sp.

ADK2 producing glycolipid biosurfactant

Secondary screening (quantitative screening): For more detection and meticulous selection of efficient bacterial isolate to produce biosurfactant, two of Lactobacillus spp. Were selected from primary screening methods and screened again for biosurfactant production by cultivated them in MSM containing $1 \%$ peanut oil as a carbon source to induce them to produce biosurfactant, in different condition extracellular and intracellular.

\section{Determination surface tension}

The results of surface tension was measured by tensiometer and showed a high biosurfactant activity, ranging between (23.27 $-33.87 \mathrm{mN} / \mathrm{m}$ in anaerobic condition) while ( 28.87-37.71 $\mathrm{mN} / \mathrm{m}$ in aerobic condition). ADK2 isolate revealed a higher reduction of surface tension $(23.27 \mathrm{mN} / \mathrm{M})$ in anaerobic conditions. Notice the detection of important surface activity of biosurfactants recovered from cells (cell-bound biosurfactant) or from culture supernatant (excreted biosurfactant). Rodrigues et al, (41) suggests that at least for isolate L. rhamnosus L61, the existence of a mixture or several compounds with surface active properties. Similar aspects were detected for L.paracasei biosurfactants. The low molecular weight biosurfactant are able to reduce the surface tension below $40 \mathrm{mN} / \mathrm{m}$, while the high molecular weight bioemulsifiers can form and stabilize emulsions without remarkable surface tension reduction (41). After $120 \mathrm{~h}$ of incubation at $30^{\circ} \mathrm{C}$ with steady favorite conditions, the surface tension of solution of RL reached its minimum value $(27.2 \quad \mathrm{mN} / \mathrm{m})$ with emulsification activity $67 \%$ and biomass 2.7 $\mathrm{g} / \mathrm{l}$ by Alshaikh Faqri et al, (3).

Determination of emulsification activity $(E$ 24\%): The emulsification activity of biosurfactant produced extracellular and intracellular by selected lactobacilli was measured by toluene with bacterial supernatant. The results showed that the isolates were able to produce biosurfactant with a variable emulsification activity ranging (21\%-66\% in anaerobic condition) while (12\%-53\% in aerobic condition. The isolates (ADK2) showed the highest $\mathrm{E}_{24}$ activity $66 \%$ in anaerobic and cell bound conditions as Figure 10. Organisms with high emulsifying activity are promising microbial candidates for biosurfactant production., the highest value of emulsification index was found in $L$. plantarum compared to other isolates. This reveals that it is an emulsifier and has the ability to reduce surface tension (42). For another studies L.rhamnosus and L. fermentum showed high emulsifying ability (43).

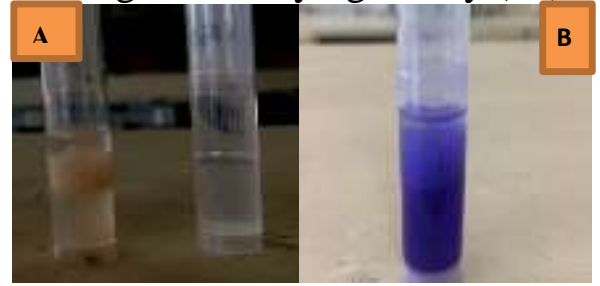

Figure 10. Emulsification index (E24\%) of isolate in toluene (A): isolate ADK2 producing E24\% (B): staining with crystal violet. (C): control

Bacterial adhesion to hydrocarbons

Cell adherence with hydrophobic compounds like diesel oil is considered as an indirect method to screen bacteria for biosurfactant production, because cells attach themselves with oil droplets by producing surface active compounds called biosurfactants. The two isolates used in the present study were found to be positive for the BATH assay, which is indicative the affinity of the bacterial cells towards hydrophobic substrate. Cell adherence found for above positive isolates with motor oil was in the range of $(2 \%-89 \%$. In anaerobic condition) while (2\% - 63\% in(aerobic conditions). ADK2 isolate supernatant contain a higher cell adherence of $89 \%$ with motor oil in anaerobic and cell bound conditions. BATH assay results 
revealed that a high cell adherence of $93.2 \pm$ $1.2 \%$ was found for $L$. delbrueckii cells with crude oil, which directly correlated with the biodegradation potential observed in this study for this strain. Similar high cell hydrophobicity and degradation reported by Sauvageau (44) for $P$. aeruginosa support the results obtained in this study.

\section{Identification Lactobacillus spp. Isolate}

In order to undertake the molecular analysis, DNA was extracted from the putative Lactobacillus sp. ADK2 isolate. In studies of bacterial populations associated with genomic pollution, Lactobacillus derived DNA, which is readyiyl amplified with general bacterial

Table 3. Data analysis of Lactobacillus species ADK2 on NCBI by using general gene 16s ribosomal RNA gene

\begin{tabular}{|ccccccc|}
\hline Description & $\begin{array}{c}\text { Max } \\
\text { Score }\end{array}$ & $\begin{array}{c}\text { Total } \\
\text { Score }\end{array}$ & $\begin{array}{c}\text { Query } \\
\text { cover }\end{array}$ & $\begin{array}{c}\text { E } \\
\text { value }\end{array}$ & Ident & Accession \\
\hline $\begin{array}{c}\text { Lactobacillus plantarum } \\
\text { strain CAU7087 16S } \\
\text { ribosomal RNA gene, partial } \\
\text { sequence }\end{array}$ & 1725 & 1725 & $99 \%$ & 0 & $99 \%$ & $\begin{array}{c}\text { MF4 } \\
\text { (175 }\end{array}$ \\
\hline
\end{tabular}

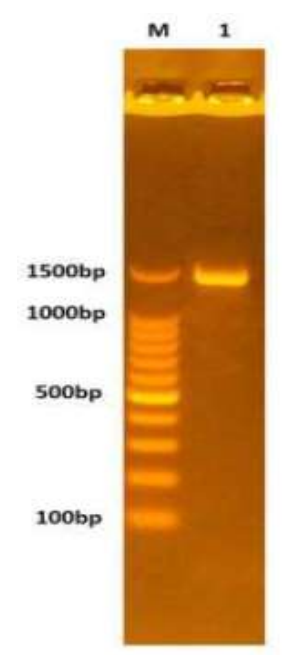

Figure 11. Agarose gel electrophoresis of Lactobacillus isolate with $27 \mathrm{~F}$ and $1492 \mathrm{R}$ primers set (the first line are positive

Lactobacillus plantarum isolate, M: marker) visualized under UV staining with ethedium promide (agarose con. $1 \%$ and run with $5 \mathrm{~V} / \mathrm{cm}$

Optimum conditions for biosurfactant production

Effect of fermentation media : The influence of different fermentation media on the production of biosurfactant was tested by cultivating the isolate $L$. plantarum ADK2 in four different media, namely A: synthetic media (Mineral Salt, and MRS media) B: New natural media (BCDFTM and whey). After incubation, emulsifying activity and surface primer sets, can be easily detected following DNA extraction and subsequent PCR amplification. Here, using such general primers $(27 \mathrm{~F} / 1492 \mathrm{R})$ band were detected confirming the identity of the putative isolate as member of the genus Lactobacillus therefor the isolate ADK2was designated as Lactobacillus plantarum and selected for the remaining studied as in Figure 11. Analysis on sequences and confirmation of microorganism's homogenic data using rRNA database (NCBI) after amplification of Bacteria RNA ribosomal result indicate as (Table 3).

tension of supernatant were determined. Among the four media used, the new natural media (BCDFTM) was found to be the best medium for biosurfactant production as indicated by the results of emulsifying activity and surface tension. The highest emulsifying activity $(63 \%)$ and lowest surface tension $(22.08 \mathrm{mN} / \mathrm{m})$ were observed with BCDFTM , while in synthetic media (MSM) the highest emulsifying activity (60\%) and lowest surface tension $(24.90 \mathrm{mN} / \mathrm{m})$ were observed. The other media give variable results as show in Figure 12.Therefore, this medium (BCDFTM and MSM) was selected to determin the optimum conditions for other fermentation parameters.

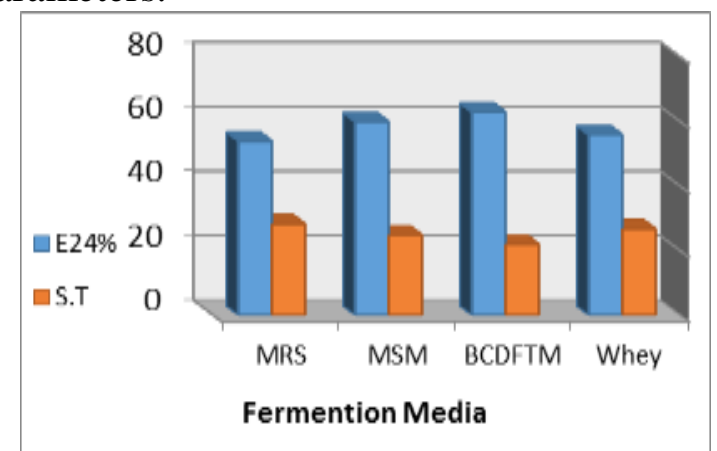

Figure 12. Effect of different fermentation media on biosurfactant produced by $L$. plantarum (ADK2), pH 6.2, at $37^{\circ} \mathrm{C}$ in shaker incubator $150 \mathrm{rpm}$ after 3 days in anaerobic conditions by using $\mathrm{N} 2$ gas 


\section{Effect of Ph}

To investigate the effect of initial $\mathrm{pH}$ medium on biosurfactant production by $L$. plantarum ADK2, mineral salt medium and new natural media which selected in previous study were adjusted to different $\mathrm{pH}$ values. The obtained results in Figure 13 indicate that the highest emulsifying activity (64\%) and lowest surface tension $(21.18 \mathrm{mN} / \mathrm{m})$ occurred with $\mathrm{pH} 3$ using new natural media, while in synthetic media (MSM) the highest emulsifying activity $(58 \%)$ and lowest surface tension (25.08 $\mathrm{mN} / \mathrm{m}$ ) observed with $\mathrm{pH} 5$. It was also shown that a good activity was recorded with $\mathrm{pH}$ values between 4 to 9 by using new natural media compared with synthetic media. The synthesis of the biosurfactant decreased without the $\mathrm{pH}$ control, indicating the importance of maintaining it throughout the fermentation process (45). Environmental factors and growth conditions such as $\mathrm{pH}$ effect on biosurfactant production through their effects of cellular growth or activity. When the $\mathrm{pH}$ is maintained at 5.5, the production of glycolipids reaches a maximum by Candida antarctica, $C$. apicola, and rhamnolipid production by Pseudomonas spp. reached its maximum at a $\mathrm{pH}$ 7.(46)

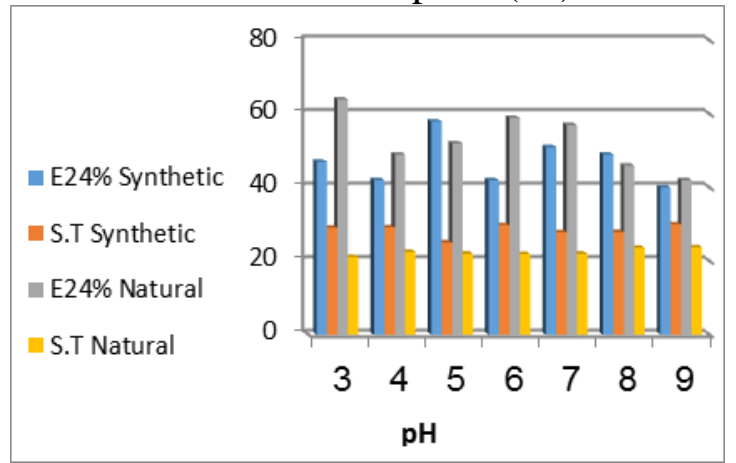

Figure 13. Effect of $\mathrm{pH}$ values of biosurfactant production by $L$. plantarum (ADK2), at $37^{\circ} \mathrm{C}$ in shaker incubator 150 rpm after 3 days, Synthetic media and Natural BCDFTM media in anaerobic

\section{Effect of temperature} conditions by using $\mathrm{N} 2$ gas

The temperature is one of the most important parameters affecting on the production of biosurfactant, so different incubation temperatures were used. Results in Figure 14 show that the optimal temperature for biosurfactant production was $30{ }^{\circ} \mathrm{C}$ with an emulsification activity $80 \%$ and a surface tension $20.91 \mathrm{mN} / \mathrm{m}$ when natural media used, while the synthetic media recorded higher biosurfactant production at $30^{\circ} \mathrm{C}$ with an emulsification activity $59 \%$ and a surface tension $23.28 \mathrm{mN} / \mathrm{m}$, the results also showed the capability of isolate L. plantarum ADK2 to grow and produce biosurfactant at wide range of temperatures include $15,44,53$ and $60^{\circ} \mathrm{C}$. Tthe constancy of production between $30^{\circ} \mathrm{C}$ and $37^{\circ} \mathrm{C}$, while these was decreasing were at both sides of this range (37). The $60{ }^{\circ} \mathrm{C}$ was the optimum temperature for biosurfactant production by Geobacillus. pallidus (22). Temperature is one of the important factors for biosurfactant production. Temperature influencing the rates of biochemical reactions either by inducing or repressing enzyme production. temperature causes alteration in the composition of the biosurfactant produced (25).

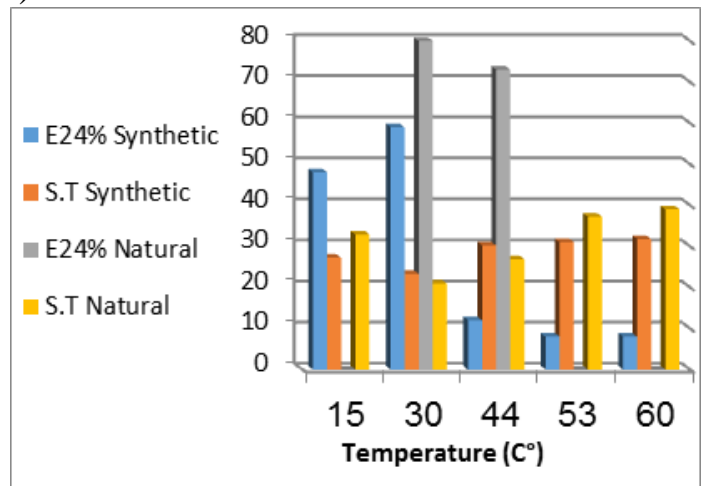

Figure 14. Effect of incubation temperature on biosurfactant produced by L.plantarum (ADK2), in shaker incubator $150 \mathrm{rpm}$ after 3 days, Synthetic media $\mathbf{p H} 5$ and Natural BCDFTM pH 3 in anaerobic conditions by using $\mathbf{N} 2$ gas .

Effect of agitation speed

The agitation represents another important factor influencing on the biosurfactant production. To evaluate the effect of the agitation, the cultures were incubated at different agitation speed (rpm) values ranging between 120-220 rpm. The results in Figure 15 illustrated that maximum E24\% (81\%) with reduction in surface tension $(20 \mathrm{mN} / \mathrm{m})$ and $\mathrm{E} 24 \%(59 \%)$ with reduction in surface tension $(22.80 \mathrm{mN} / \mathrm{m})$ were obtained at $120 \mathrm{rpm}$ for natural and synthetic media .Dastgheib et al, (11) who noticed that the optimum agitation speed was $200 \mathrm{rpm}$ when the biosurfactant was produced by thermophillic Geobacillus pallidus. The biosurfactant production by Bacillus subtilis and $P$. aeruginosa was 
optimized in a shaker operating at $120 \mathrm{rpm}$ (24). The effect of rotation velocity (agitation) on the biosurfactant concentration and surface tension reduction was tested at 150 and 200 rpm. considered an important factor for cell growth and biosurfactant production. It may also be linked to the physiological function of microbial emulsifier, it has been suggested that the production of bioemulsifiers can enhance the solubilization of water insoluble substrates and consequently facilitate nutrient transport to microorganisms (58)..

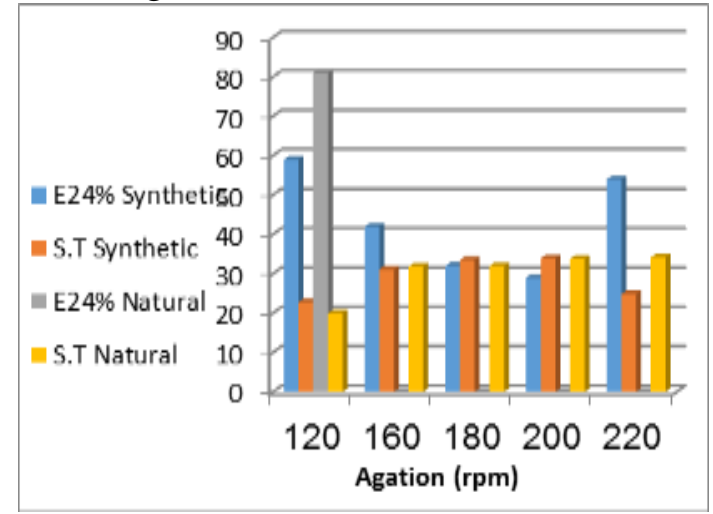

Figure 15. Effect of rpm values on biosurfactant production by L.plantarum (ADK2) grown in MSM, pH 5, and BCDFTM pH 3, at $30^{\circ} \mathrm{C}$ in shaker incubator after 3 days in anaerobic conditions by using $\mathrm{N}_{2}$ gas

\section{Effect of carbon sources}

Biosurfactant production was tested in the presence of different carbon sources which incorporated in to the production medium with concentration of $1 \%(\mathrm{w} / \mathrm{v})$. Results indicate in Figure 16: A and B that the E24\% reached to $(79 \%$ and $63 \%)$ and surface tension (21.02, $25.41 \mathrm{mN} / \mathrm{m}$ ) were achieved when egg and lactose were used as the sole source of carbon and energy respectively, followed by chasses and fructose with(E24 71\% and E2457 \%) and surface tension (23.35 and $28.38 \mathrm{mN} / \mathrm{m})$ respectively. While the lowest activity was obtained (44\% with $29.77 \mathrm{mN} / \mathrm{m}$ and $0 \%$ with $36.88 \mathrm{mN} / \mathrm{m}$ ) respectively when used beef and glycerol. These results demonstrated the ability of this bacterium to degrade a wide range of carbon sources and biosurfactant production. The crude motor oil enhanced the biosurfactant production from $P$. aeruginosa PBSC1 with a surface tension $30.98 \mathrm{mN} / \mathrm{m}$ and an emulsification index of $74.32 \pm 0.52 \%$ (23) While (36) found that the B. licheniformis PTCC produced biosurfactant when growing on almond, castor and olive oil as sole carbon source, but the maximum yield was achieved with olive oil. Also Wei et al, (58) mentioned that the surfactin production by B. subtilis 573 was evaluated using the corn steep liquor as an alternative low-cost culture medium.

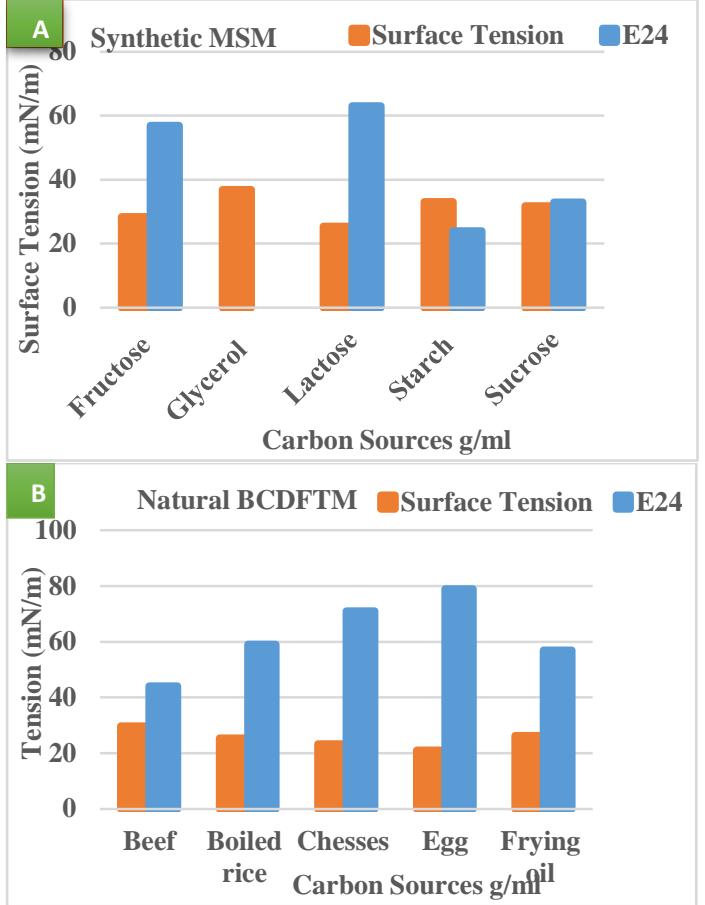

Figure 16. Effect of carbon sources on biosurfactant produced by L.plantarum (ADK2), at $30^{\circ} \mathrm{C}$ in shaker incubator 120 rpm after 3 days, in anaerobic conditions by using N2 gas. (A): Synthetic media pH 5,

(B): Natural BCDFTM pH3

Effect of egg and lactose concentration

Different concentrations of the optimal carbon source (egg and lactose) were used to determine the best concentration for biosurfactant production by $L$. plantarum ADK2. Results in Figure 17 indicate that the gradual increase of carbon source concentration was accompanied by an increase in the emulsification activity and decrease of surface tension, which was an indicator of biosurfactant production, till the optimum carbon concentration. These dramatic changes in emulsification activty and surface tension reached to its better values $(78 \%$ and 20.05 $\mathrm{mN} / \mathrm{m}$ and $61 \%$ and $24.22 \mathrm{mN} / \mathrm{m}$ ) respectively at a concentration of $1.5 \%$ of egg and lactose. The higher concentration of carbon source may reflect the toxic effect to the producing organisms (11). 


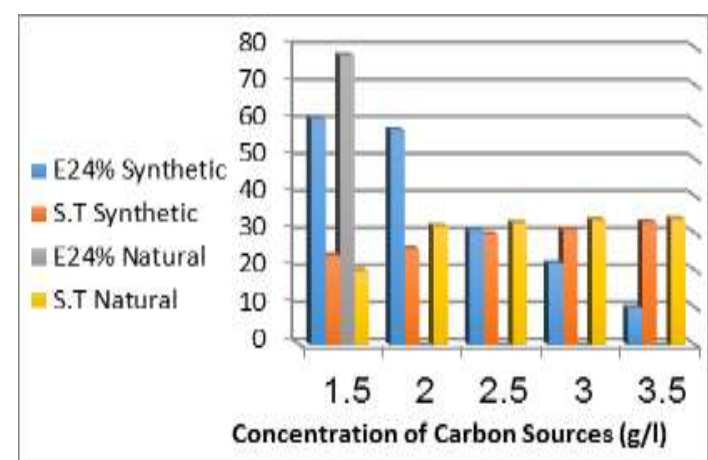

Figure 17. Effect the concentration of carbon sources on biosurfactant produced by $L$. plantarum (ADK2), at $30^{\circ} \mathrm{C}$ in shaker incubator $120 \mathrm{rpm}$ after 3 days, Synthetic media pH 5 (lactose) and Natural BCDFTM pH 3 (egg). in anaerobic conditions by using $\mathbf{N} 2$ gas .

Effect of nitrogen sources: In order to determine the effect of different types of nitrogen sources on biosurfactant production by L.plantarum. ADK2, different in nitrogen surces were tested. Results in Figure 18 : A and $\mathrm{B}$ showed that the production of biosurfactant varies with different nitrogen sources. The highest E24\% (64\%) with lowering the surface tension of $(22.18 \mathrm{mN} / \mathrm{m})$ were obtained when peas was used as nitrogen source, while the highest E24\% (59\%) with minimum surface tension of $(26.3 \mathrm{mN} / \mathrm{m})$ observed when meat extract was used. While the lowest emulsification activity and surface tension observed with chickpeas and urea $(51 \%$ and $27.30 \mathrm{mN} / \mathrm{m}$ and $42 \%$ and 31.20 $\mathrm{mN} / \mathrm{m}$ ) respectively, compared with other nitrogen sources. The bacteria require nitrogen to complete its metabolic pathways and it is essential for the microbial growth as protein and enzyme syntheses depend on it (2). The ammonium salts and urea were preferred nitrogen sources for biosurfactant production by Arthrobacter paraffineus, whereas nitrate supported the maximum surfactant production by $P$. aeruginosa and Rhodococcus sp (23). However, the potassium nitrate support the maximum production of biosurfactant by the yeast Rhodotorula glutinis IIP30 (11).

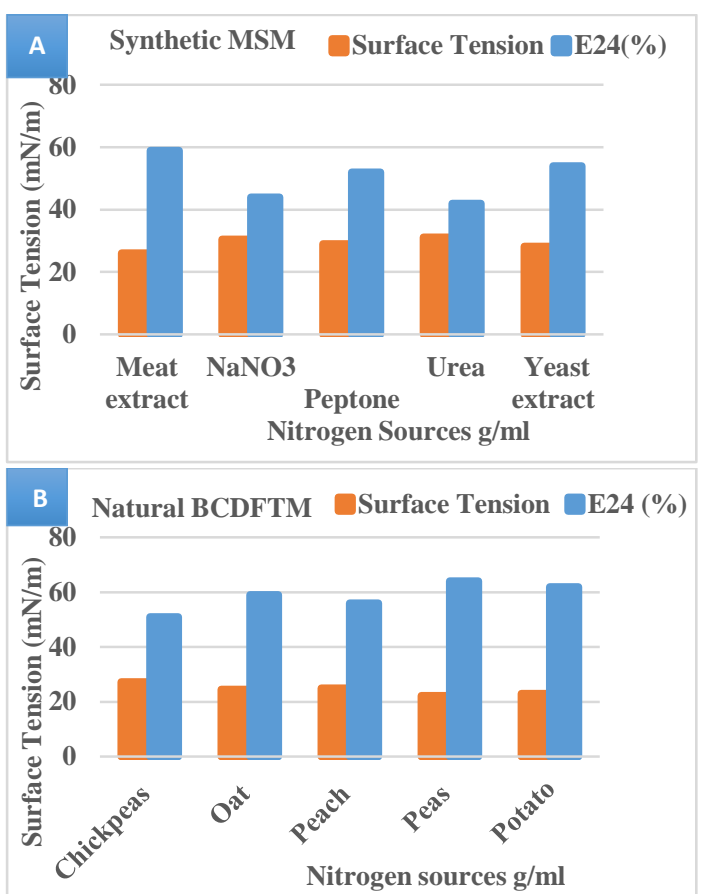

Figure 18. Effect of nitrogen sources on biosurfactant produced by L.plantarum (ADK2), at $30{ }^{\circ} \mathrm{C}$ in shaker incubator 120 rpm after 3 days, in anaerobic conditions by using N2 gas. (A): Synthetic media pH 5,

(B): Natural media BCDFTM pH 3.

Effect of peas and yeast extract concentration

Different concentrations of peas and meat extract were used as nitrogen source to determine the optimum concentration for biosurfactant production by $L$. plantarum ADK2. Results in Figure 19 illustrated that the maximum E24\% $66 \%$ and $58 \%$ and minimum surface tension 23.03 and $28.30 \mathrm{mN}$ / $\mathrm{m}$, were obtained when peas and meat extract were added in a concentration of $3.5 \%$ and 2 $\%(\mathrm{w} / \mathrm{v})$ respectively. The results also showed a reduction in emulsification activity and increases in surface tension when the concentration of peas or meat extract were below or above $3.5 \%$ and $2 \%$. The best nitrogen source for emulsifier production by Bacillus licheniformis was $2 \%$ of sodium nitrate (24). While Vandana and Peter (56) detected that the production of biosurfactant often occurs when the nitrogen source is depleted in the culture medium, during the stationary phase of cell growth, as an example the biosurfactant production increased by $P$. aeruginosa, Candida tropicalis IIP-4 and Nocardia strain SFC-D due to the nitrogen limitation. 


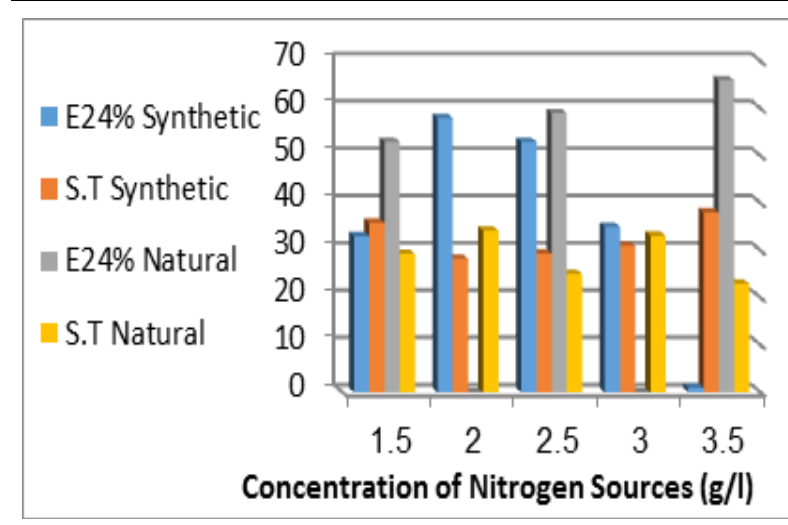

Figure 19. Effect of concentration of nitrogen sources on biosurfactant produced by $L$. plantarum ADK2, at $30{ }^{\circ} \mathrm{C}$ in shaker incubator $120 \mathrm{rpm}$ after 3 days, Synthetic media pH 5 (meat extract) and Natural BCDFTM pH 3 (peas). in anaerobic conditions by using $\mathbf{N} 2$ gas

\section{Effect of incubation period}

Different incubation periods (0-144 hr.) were examined to detect the optimal periods of bacterial growth and biosurfactant production by L. plantarum ADK2. Results in Figure 20 showed that the maximum E24\% (88\%) and the lowest surface tension $(19.09 \mathrm{mN} / \mathrm{m})$ were obtained during $72 \mathrm{hr}$. of incubation using natural media, while the E24\% (72\%) with reduction in surface tension $(20.09 \mathrm{mN} / \mathrm{m})$ was obtained after $96 \mathrm{hr}$. using synthetic media. Whereas after 72 and 96 hrs. of incubation, the emulsification activity was decreased and with an increasing the surface tension values with increasing the incubation time. This may be due to the change in the culture conditions along this periods such as diminishing of an anaerobic conditions, nutrients and accumulating of toxic metabolites which inhibit the bacterial growth. The result in the current study pointed that biosurfactant produced by Lactobacillus plantarum ADK2 increased with incubation period and the production starded at early stationary phase (48h) and reached maximum at 96 and $72 \mathrm{~h}$ for synthetic and natural media beyond above incubation time both growth and biosurfactant production decrase. Bonilla et al, (7) mentioned that the biosurfactant biosynthesis stopped, probably due to the production of secondary metabolites which could interfere with emulsion formation and the adsorption of surfactant molecules at the oil-water interface. A maximum emulsan production by Acenitobacter calcoaceticus RAG-1 during the stationary growth phase (39). While Vandana and Peter (56) were showed that the biosurfactant biosynthesis using olive oil occurred predominantly during the exponential growth phase, suggesting that the biosurfactant was produced as a primary metabolite accompanying cellular biomass formation (growth-associated kinetics). The RL production was increased with time until it reaches the maximum level after $108 \mathrm{~h}$ of incubation where $10.6 \mathrm{~g} / \mathrm{L}$ was obtained by Alshaikh Faqri et al, (2)

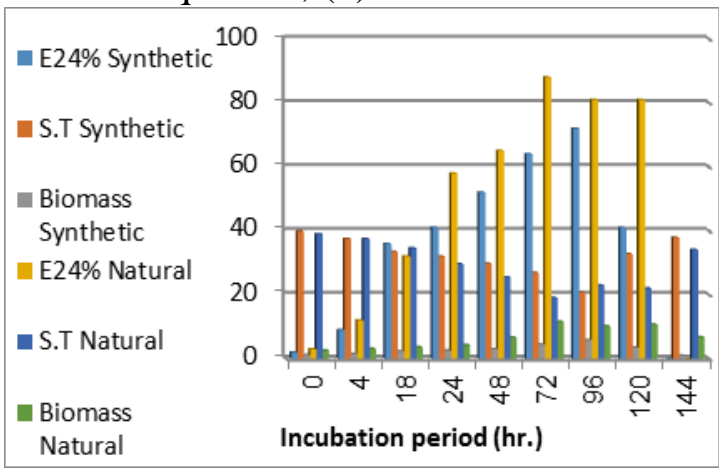

Figure 20. Effect of incubation period on $L$. plantarum (ADK2) grown in synthetic (MSM) pH 5, and natural (BCDFTM) pH 3, at $30^{\circ} \mathrm{C}$ in shaker incubator $120 \mathrm{rpm}$ after 3 days. in anaerobic conditions by using $\mathrm{N} 2$

Antimicrobial activity of crude biosurfactant: To evaluate the antimicrobial effects of biosurfactants produced by selected isolate, L. plantarum ADK2 was screened for inhibitory activity against pathogenic bacteria. Results in Figure 21 show that the biosurfactants had an inhibitory effect against some of pathogenic bacteria such as $S$. aureus and $P$. aeruginosa. Antimicrobial activity of supernatant from ADK2 isolate had a high inhibitory effect against $S$. aureus and $P$. aeruginosa with $34.18, \quad 38.43 \mathrm{~mm}$ respectively. This effect may be attributed to the structure of biosurfactant, it is supposed to exert its toxicity on the cell membrane permeability as detergent like effect that emulsified lipid bacterial membranes and/or form a pore-bearing channel inside a lipid membrane. The biosurfactants produced by Streptococcus thermophilus and L. lactis showed significant antimicrobial activity against several bacterial and yeast strains isolated from explanted voice prostheses (52). The antimicrobial activity of the crude biosurfactant isolated from $S$. thermophilus 
and L.lactis observed against $S$. aureus and $S$. epidermidis was which completely inhibited the growth of those bacteria with concentrations $100 \mathrm{mg} / \mathrm{ml}$ (5). This effect may be attributed to the structure of biosurfactant, it is supposed to exert its toxicity on the cell membrane permeability as detergent like effect that emulsified lipid bacterial membranes and/or form a pore-bearing channel inside a lipid membrane. found that the effect of lipopeptide biosurfactant. was attributed to self-associate and form a pore-bearing channel was due to the ability of micellular aggregate inside a lipid membrane(13).

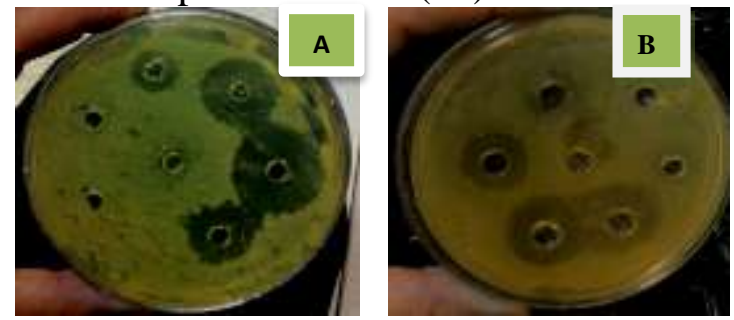

Figure 21. Antimicrobial activity of Biosurfactant producing isolate ADK2 against pathogenic isolates (A) $P$. aeruginosa $(B)$ S. aureus. Biosurfactant

\section{REFERENCES} grown on MSM.

1. Abu-Ruwaida, A. S., L. M. Banat, S. Haditirto and A. Khamis. 1991. Nutritional requirements and growth characteristics of a biosurfactant producing Rhodococcus bacterium. World. J. Microbiol., 7:53-61

2. Alshaikh Faqri, A. M., N. H. Hayder and A. J .Hashim 2019. Induction of rhamnolipid production by pseudomonas aeruginosa A3 using chemical and physical mutagenic factors. Iraqi Journal of Agricultural Sciences.50 (4):1174- 1185

3. Alshaikh Faqri, A. M., N. H. Hayder and A. J. Hashim. 2019. Lab-scale production of rhamnolipid by pseudomonas aeruginosa A3 and study its synergistic effect with certain antibiotics against some. Iraqi Journal of Agricultural Sciences. 50(5):1290-1301

4. Anandaraj, B. and P. Thivakaran. 2010. Isolation and Production of Biosurfactant producing organism from oil spilled soil. J. Biosci Tech., 1 (3): 120-126

5. Bednarski, W., M. Adamczak and J. Tomasik. 2004. Application of oil refinery waste in the biosynthesis of glycolipids by yeast. Bioresource Technology. 95: 15-18
6. Belcher, R.W., K.V. Huynh, T.V. Hoang and D.E. Crowley.2012. Isolation of biosurfactant-producing bacteria from the Rancho La Brea Tar Pits. World J. Microbiol Biotechnol 28: 3261-3267

7. Bonilla, M.. C. Olivaro, M. Corona, A. Vazquez and M. Soubes. 2005. Production and characterization of a new bioemulsifier from P. putida ML2, J. Appl. Microbiol., 98: 456463

8. Chen, C., S.C. Baker and R. Darton. 2007. The application of a high throughput analysis method for the screening of potential biosurfactants from natural sources. J. Microbiol Method,; 70: 503-510 .

9. Cohen, R. and D. Exerowa. 2007. Surface forces and properties of the foam films from rhamnolipids biosurfactants. Adv. Colloid Interface Sci,; 134-135: 24-34

10. Das, P., S. Mukherjee and R. Sen. 2009. Substrate dependent production of extracellular biosurfactant by a marine bacterium Bioresource Technology., 100 : 1015-1019

11. Dastgheib, S. S. M., M. A. Amoozegar, E. Elahi, S. Asad and I. M. Banat. 2008. Bioemulsifier production by a halothermophilic Bacillus strain with potential applications in microbially enhanced oil recovery. Biotechnol. Lett., 30:263-270

12. De Man, J. C. , M. Rogosa and M. E Sharpe. 1960. A medium for the cultivation of Lactobacilli. J. Appl. Bacteriol. 23: 130 - 135. Cited By: Boris, S. ; Suarez, J. E. ; and Barbes, C. (1997). Charaterization of the aggregation promoting factor from Lactobacillus gasseri a vaginal isolates. J. Appl. Microbiol. 83: 413 - 420.

13. Deleu, M., M. Paquot and T. Nylander. 2008. Effect of fengycin, a lipopeptide produced by $B$. subtilis on model biomembranes. Biophys. J., 94:2667-2679

14. Erum, S., B. Uzma, A. Jameela, A. A. Faiza, W. Maheen and A. A. Maqsood. 2012. Screening of surfactant producing bacterial strains isolated from soil samples of an Automobile Workshop, Karachi University Journal of Science, 40, 31-36

15. Feigner, C., F. Besson and G. Michel. 1995. Studies on lipopeptide biosynthesis by Bacillus subtilis: isolation and characterization 
of iturin, surfactin mutants. FEMS Microbiology Letters 127: 11-15

16. Fernandes, P.A.V., I.R. Arruda, A.F.B. Santos, A.A. Araujo, A.M.S. Maior and E.A.Ximenes.2007.Antimicrbial activity of surfactants produced by Bacillus subtilis R14 against multidrug resistant bacteria. Braz. J. Microbiol,; 38: 704-709

17. Fischer, E. and R. Munoz.1947. J. Bact., 53: 381-388

18. Ghribi, D., L. Abdelkefi-Mesrati, I. Mnif, R. Kammoun, I.Ayadi,, I. Saadaoui, S.Maktouf and S. Chaabouni-Ellouze. 2012. Investigation of Antimicrobial Activity and Statistical Optimization of Bacillus subtilis SPB1 Biosurfactant Production in Solid-State Fermentation. Journal of Biomedicine and Biotechnology. 2012: 12

19. Gudina, E.J., J.A.,V. Rocha, L.R. Teixeira and Rodrigues. 2010. Antimicrobial and antiadhesive properties of a biosurfactant isolated from Lactobacillus paracasei ssp. paracasei A20, Lett. Appl.Microbiol. 50(4): p.419-424

20. Hanen, B.A., J. Nawel, M. Hana, B. Ahmed, and H. Noomen. 2015. Enhancement of solubilization and biodegradation of dieseloil by biosurfactant by Bacillus amyloliquefaciens An6. Int Biodeterior Biodegradation;99:8-14

21. Holt, J. C. , N. R. Krieg, A. Sneath, J. T. Staley, and S. T. Williams. 1994. Bergey's manual of systemic bacteriology. 9th ed. Williams and Wilkins, Baltimore, London 22. Hugas, M., M. Garriga, T. Aymerich and J.M. Monfort.1993. Biochemical characterization of lactobacilli from dry fermented sausages. Int. J. Food Microbiol; 18: $107-113$

23. Johnson, V., M. Singh and V. S. Saini. 1992. Bioemulsifier production by an oleaginous yeast Rhodotorula glutinis IIP-30. Biotechnology Letters., 14: 487-490

24. Joice, P. A. and R .Parthasarathi.2014. Optimization of biosurfactant production from P. aeruginosa PBSC1. Int. J. Curr. Microbiol. App. Sci., 3(9):140-151

25. Joice, P. A. and R. Parthasarathi. 2014. Optimisation of biosurfactant production from Pseudomonas aeruginosa PBSC1. Int. J. Curr. Microbiol. App. Sci., 3:140-151
26. Joshi, S.J., H. Suthar, A.K. Yadav, K. Hingurao and A. Nerurkar. 2013. Occurrence of biosurfactant producing Bacillus sp. in diverse habitats. ISRN Biotechnology; 1-6 27. Kalyani, A. L. T., S. G. Sireesha, A. K. G. Aditya and G. G. Sankar.2014. Isolation and antimicrobial activity of rhamnolipid biosurfactant from oil-contaminated soil sample using humic-acid salts-vitamin agar. International Journal of Research in Engineering and Technology. 3(5):357-365

28. Kotzamanidis,C., A. Kourelis, E. Litopoulou-Tzanetaki, N.Tzanetakis and M. Yiangou. 2010. Evaluation of adhesion capacity,cell surfacetraits and immunomodulatory activity of presumptive probiotic Lactobacillus strains. Int. J.FoodMicrobiol. 140, 154163.doi:10.1016/j.ijfoodmicro.2010. 04.004

29. Kuiper, I., L. Ellen, R.P.Lagendijk, P.D. Jeremy, E.M.L. Gerda, E.T. Jane, J.J.L. Ben and V.B. Guido .2004. Characterization of two Pseudomonas putida lipopeptide biosurfactants, putisolvin I and II, which inhibit biofilm formation and break down existing biofilms. Mol Microbiol,; 51(1): 97113

30. Langer, O., O. Palme, V. Wray, H. Tokuda and S.Lang. 2006. Production and modification of bioactive biosurfactants, Process Biochemistry, vol. 41, no. 10, pp. 2138-2145

31. Maczek J., S. Junne and P. Götz. 2007. Examining biosurfactant producing bacteriaan example for an automated search for natural compounds. Application Note CyBio AG.

32. Madhu,N. N. and A. S. G. Prapulla. 2014. Evaluation and Functional Characterization of a Biosurfactant Produced by Lactobacillus plantarum CFR 2194. Appl.Biochem.Biotechnol., 172(4), 1777-1789 33. Morikawa, M., Y. Hirata and T. Imanaka. 2000. A study on the structure-function relationship of lipopeptide biosurfactants. Biochimica et Biophyica Acta. 1488: 211-218 34. Mukherjee, S., P. Das and R. Sen. 2006. Towards commercial production of microbial surfactants. Trends in Biotechnology, vol. 24, no. 11 , pp. $509-515$

35. Mulligan, C.N. 2005. Environmental applications for biosurfactants. Environ Pollution 133(2):183-198 
36. Noudeh, G. D., M. H. Moshafi, P. Khazaeli and F. Akef. 2007. Studies on bioemulsifier production by $B$. licheniformis PTCC 1595. American Journal of Pharmacology and Toxicology. 2 (4): 164-169 37. Okoliegbe, I. N. and O. O. Agarry. 2012. Application of microbial surfactant (areview). Scholarly Journals of Biotechnology. 1(1):1523

38. Persson, A., E. Oesterberg and M. Dostalek. 1988. Biosurfactant production by Pseudomonas fluorescens378: Growth and product characteristics. Appl. Microbiol. Biotechnol., 29(1):1-4

39. Rodrigues, L. R. and J. A. Teixeira. 2008. Biosurfactants production from cheese whey," in Advances in CheeseWhey Utilization, M. E. Cerd'an, M. Gonz'alez-Siso, and M. Becerra, Eds., pp. 81- 104, Transworld Research Network.

40. Rodrigues, L., A. Moldes, J. Teixeira and R. Oliveira. 2006. Kinetic study of fermentative biosurfactant production by Lactobacillus strains. J Biochem Eng,; 28: 109-116

41. Rodrigues, L., A. Moldes, J. Teixeira and R. Oliveira.2006b. Kinetic study of fermentative biosurfactant production by Lactobacillus strains. Biochemical Engineering Journal., 28: 109-116

42. Saharan, B. S., R. K. Sahu and D. Sharma. 2011. A Review on biosurfactants: fermentation, Current Developments and Perspectives. J. of Genetic Engineering and Biotechnol., 29

43. Saravanakumari, P. and K. Mani. 2010. Structural characterization of a novel xylolipid biosurfactant from Lactococcus lactis and analysis of antibacterial activity against multidrug resistant pathogens, Bioresource Technology, vol. 101, no. 22, pp. 8851- 8854 44. Sauvageau, J., J. Ryan, K. Lagutin, I. M. Sims, B. L. Stocker and M. S. Timmer. 2012.Isolation and structural characterization of the major glycolipids from Lactobacillus plantarum, Carbohydrate Res. 357, 151-156.

45. Sekhon, K.K., S. Khanna and S.S. Cameotra. 2012. Biosurfactant Production and Potential Correlation with Esterase Activity. J. Pet. Environ Biotechnol. 3,133

46. Sekhon, R. S., H. Lin, K. L. Childs, C. N. Hansey, C. R. Buell, N. de Leon and S. M.
Kaeppler. 2011. Genome-wide atlas of transcription during maize development. Plant J., 66(4):553-63

47. Shoeb, E., N.Ahmed, J. Akhter, U. Badar, I. K. Siddiqu, F.A. Ansari, M. Waqar, S. Imtiaz, N. Akhtar, Q.A. Shaikh, R. Baig, S. Butt, S. Khan, S. Hussain, B. Ahmed and M.A. Ansari 2015. Screening and characterization of biosurfactant-producing bacteria isolated from the Arabian Sea coast of Karachi, Turk J. Biol., 39, 210-216.

48. Simoes, M., L.C. Simoes and M.J. Vieira. 2010. A review of current and emergent biofilm control strategies. LWT- Food Sci Technol,; 43(4): 573-583

49. Stearn, E. W. and A. E. Stearn. 1928. Univ. Missouri Studies, 3, 51

50. Stoyanova, L.G , N. L. Olsinskaya and L. I. Vorobjeva. 1979. The ability of propionbacteria to grow in liquid eggs and to ferment all the carbohydrates of egg white in 24 h.ISBN. 0-7923-5884-8 .

51. Sumathip, R. and N. Yogananth. 2016. Isolation and identification of Biosurfactant producing Pseudomonas aeruginosa from marine sediment samples and its Antimicrobial Properties. Int. J. Adv. Res. Biol. Sci.3:200-12 52. Tahmourespour, A., R. Salehi and R. H. Kermanshahi. 2011. Lactobacillus acidophilus-derived biosurfactant effect on $\mathrm{gtfb}$ and gtfc expression level in streptococcus mutans biofilm cells. Brazilian Journal of Microbiology 42: 330-339

53. Thavasi, R., S. Jayalakshmi and I.M. Banat. 2011. Effect of biosurfactant and fertilizer on biodegradation of crude oil by marine isolates of Bacillus megaterium, Corynebacterium kutscheri and Pseudomonas aeruginosa. Bioresour. Technol. 102 (2), 772778

54. Thavasi,R., S. Jayalakshmi, and I.M. Banat. 2011.Application of biosurfactant produced from peanut oil cake by Lactobacillus delbrueckii in biodegradation of crude oil," Bioresource Technology, vol. 102, no. 3, pp. 3366-3372

55. Tugrul, T. and E. Cansunar. 2005. Detecting surfactant producing microorganisms by drop-collapse test. World Journal of Microbiology and Biotechnology 21: $851-853$ 
56. Vandana, P. and J.K. Peter. 2014. Partial purification and characterization of biosurfactant from Pseudomonas aeruginosa (C). Int. J. Eng. Sci. Res Technol;3:45-50

57. Vollbrecht, E., R. Heckmann, V. Wary, M. Nimtz and S. Lang. 1998. Production and structure elucidation of di- and oligosaccharide lipids (biosurfactant) from Tsukamurella sp. Appl. Microbial Biotechnol. 50: 530-537

58. Wei, Y.H., C. L. Chou and J.S. Chang. 2005. Rhamnolipid production by indigenous pseudomonas aeruginosa $\mathrm{J} 4$ originating from petrochemical wastewater. Biochemical Engineering Journal. 27:146-154

59. Yalçin, E. and A. Ergene. 2009. Screening the antimicrobial activity of biosurfactants produced by microorganisms isolated from refinery waste waters. Journal of Applied Biological Sciences. 3 (2): 148 - 153

60. Zheng, C., J. He, Y. Wang, M. Wang and Z. Huang. 2011. Hydrocarbon degradation and bioemulsifier production by thermophilic $G$. pallidus strains. Bioresource technology. 102:9155- 9161. 